\title{
PENDIDIKAN KESEHATAN KELUARGA EFEKTIF MENINGKATKAN KEMAMPUAN IBU DALAM MERAWAT ANAK DIARE
}

\author{
Ni Luh Kompyang Sulisnadewi $i^{1,2^{*}}$, Nani Nurhaeni ${ }^{3}$, Dewi Gayatri ${ }^{3}$ \\ 1. Poltekkes Kemenkes Denpasar Jurusan Keperawatan, Bali 80222, Indonesia \\ 2. Program Studi Magister Fakultas Ilmu Keperawatan Universitas Indonesia, Depok 16424, Indonesia \\ 3. Fakultas Ilmu Keperawatan Universitas Indonesia, Depok 16424, Indonesia \\ 4. Fakultas Kesehatan Masyarakat Universitas Indonesia, Depok 16424, Indonesia \\ *Email:dewisulisna@yahoo.co.id
}

\begin{abstract}
Abstrak
Diare merupakan salah satu penyebab tingginya morbiditas dan mortalitas anak di Indonesia. Salah satu faktor risiko terjadinya diare dan meningkatkan risiko anak untuk dirawat inap adalah kurang pengetahuan ibu. Penelitian ini bertujuan untuk mengidentifikasi pengaruh pendidikan kesehatan terhadap kemampuan ibu merawat anak diare. Penelitian ini merupakan studi kuasi eksperimen dengan rancangan post-test only with group control design. Sampel penelitian sebanyak 62 responden di dua rumah sakit di Denpasar. Hasil post-test menggambarkan bahwa skor pengetahuan, sikap, dan keterampilan masingmasing kelompok berbeda secara bermakna $(p<0,05)$ dan ibu pada kelompok intervensi mampu merawat anak diare, berbeda secara bermakna dengan kelompok kontrol $(\mathrm{p}=0,000 ; \alpha=0,05)$. Pendidikan kesehatan perawatan anak diare hendaknya diberikan secara intensif guna mendukung terlaksananya konsep family centered care dalam asuhan keperawatan anak di rumah sakit.
\end{abstract}

Kata kunci: diare, kemampuan ibu, keterampilan, pengetahuan, sikap

\begin{abstract}
Diarrhea is one of the causes of high morbidity and mortality of children in Indonesia. One risk factor for diarrhea and increased risk for hospitalized children is the lack of maternal knowledge. The study aimed to identify the effect of health education for maternal ability in caring for child with diarrhea. This research was a quasi-experimental study, using control group post-test only design. Study sample was 62 respondents in two hospitals in Denpasar. The results indicated that posttest scores of knowledge, attitudes and skills of each group were different significantly $(p<0.05)$. Mothers in the intervention group capable of caring for child with diarrhea, significantly different to those in the control group $(p=0.000 ; \alpha=0.05)$. Health education about diarrhea in children should be given intensively to support the implementation of family centered care concept in pediatric nursing at hospital.
\end{abstract}

Keywords: diarrhea, maternal ability, skills, knowledge, attitudes

\section{Pendahuluan}

Diare masih merupakan salah satu penyebab tinggi morbiditas dan mortalitas anak di Indonesia. Salah satu faktor telah teridentifikasi sebagai faktor risiko mempengaruhi terjadinya diare dan meningkatkan risiko anak dirawat inap karena diare adalah kurang pengetahuan orangtua khususnya ialah ibu dalam mencegah maupun merawat anak dengan diare.

Diare pada umumnya termasuk penyakit yang dapat sembuh dengan sendirinya (self limiting disease) (Subagyo \& Santoso, 2011). Penanganan yang tepat, akan menurunkan derajat keparahan penyakit sehingga anak tidak memerlukan rawat inap. Pada kenyataannya angka rawat inap pasien dengan diare akut masih cukup tinggi. Data surveilen terpadu berbasis rumah sakit di Propinsi Bali pada 2009 menunjukkan proporsi anak dengan diare yang dirawat sebesar 29\%. Proporsi anak yang dirawat dengan diare sampai Oktober 2010 meningkat menjadi $32 \%$.

Khalili (2006) menjelaskan bahwa salah satu faktor risiko yang menyebabkan pasien dengan diare dirawat di rumah sakit di negara berkembang adalah tingkat pendidikan dan tingkat pengetahuan orangtua yang rendah tentang perawatan diare. 
Dalam penelitian oleh Handayani (2008); Assiddiqi (2010), menggambarkan tingkat pengetahuan ibu tentang penanganan diare sebagian besar berada pada katagori rendah sampai sedang.

Tingkat pengetahuan yang rendah akan berdampak terhadap ketidakmampuan ibu mencegah maupun merawat anak diare. Warman (2008) menemukan bahwa pengetahuan ibu memberi kontribusi paling kuat dibandingkan faktor lingkungan dan sosial ekonomi dalam mempengaruhi kejadian diare akut pada balita. Bachrach dan Gardner (2002) juga menemukan bahwa pengetahuan pengasuh yang kurang tentang rehidrasi oral, merupakan faktor yang meningkatkan risiko anak untuk mengalami dehidrasi dan dirawat di rumah sakit.

Tingkat pengetahuan ibu yang baik tentang diare, sangat menentukan dalam upaya pencegahan yang dilakukan dan upaya anak terhindar dari dampak buruk diare seperti dehidrasi, kekurangan gizi, dan risiko kematian. Pasien anak diare yang dirawat di rumah sakit membutuhkan kehadiran keluarga selama hospitalisasi. Sesuai konsep pemberdayaan keluarga dan family centered care keterlibatan orangtua dalam perawatan anak adalah sangat penting. Untuk terlibat dalam perawatan anak di rumah sakit, orangtua harus memiliki seperangkat pengetahuan dan keterampilan perawatan anaknya.

Pendidikan kesehatan sebagai bagian intervensi keperawatan mandiri dapat direncanakan untuk meningkatkan kemampuan ibu dalam merawat anak yang mengalami diare. Metode yang efektif perlu dikembangkan sehingga ibu dapat mencegah terjadi diare pada anak, melakukan penanganan yang tepat ketika anak mengalami diare dan mampu terlibat dalam perawatan anak diare di rumah sakit. Penelitian ini bertujuan untuk mengetahui pengaruh pendidikan kesehatan terhadap kemampuan ibu dalam merawat anak dengan diare.

\section{Metode}

Penelitian menggunakan desain kuasi eksperimen dengan pendekatan rancangan posttest only control group design. Sampel dalam penelitian ini adalah ibu yang memiliki anak dirawat karena diare di rumah sakit wilayah Denpasar, selama kegiatan penelitian yaitu April - Mei 2011. Kriteria inklusi penelitian adalah ibu dapat membaca dan menulis, menunggui anaknya selama dirawat, anak usia 0 59 bulan, sedangkan eksklusinya yaitu ibu dengan anak dalam kondisi kritis, ibu dalam kondisi tidak sehat, ibu memiliki anak diare dengan diagnosa penyakit lain.

Besar sampel dalam penelitian ditentukan dengan menggunakan rumus uji hipotesis beda proporsi (Ariawan, 1998). Sampel minimal yang diperlukan adalah 33 orang untuk masing-masing kelompok. Adanya keterbatasan waktu dan pasien yang sedikit dalam pelaksanaan penelitian, maka pencapaian sampel hanya sebanyak 31 orang pada masingmasing kelompok, sehingga total sampel adalah 62 orang.

Penetapan pada kelompok intervensi dan kelompok kontrol dilakukan berdasar pertimbangan tempat penelitian, dengan tujuan menghindari bias akibat interaksi dari kedua kelompok. Pengumpulan data untuk kelompok kontrol dilakukan di RS A dan kelompok intervensi di RS B Denpasar. Instrumen yang digunakan dalam penelitian yaitu kuesioner karakteristik responden, kuesioner pengetahuan, kuesioner sikap, dan lembar observasi keterampilan responden.

Analisis pada variabel-variabel dalam penelitian dilakukan secara univariat dan bivariat. Analisis univariat digunakan untuk menjelaskan variabel pengetahuan, sikap, keterampilan, dan karakteristik responden yang meliputi umur, tingkat pendidikan, pengalaman merawat anak diare di rumah sakit, dan informasi yang pernah diperoleh tentang diare. Analisis bivariat yang digunakan untuk mengetahui perbedaan pengetahuan, sikap, dan keterampilan antar kelompok dengan menggunakan independent t-test. Kemampuan ibu dinilai berdasarkan dari kriteria mempunyai dua kategori baik pada aspek pengetahuan, sikap, atau keterampilan. Kemudian kemampuan ibu antar kelompok dianalisis dengan menggunakan uji Chi-square. 
Tabel 1. Perbedaan Pengetahuan Sikap dan Keterampilan Ibu antara Kelompok Intervensi dengan Kelompok Kontrol

\begin{tabular}{lcccc}
\hline \multicolumn{1}{c}{ Variabel } & n & Mean & SD & p \\
\hline $\begin{array}{l}\text { Pengetahuan } \\
\text { a. Intervensi }\end{array}$ & 31 & 84,52 & 12,407 & $0,000^{*}$ \\
b. Kontrol & 31 & 66,45 & 17,136 & \\
Sikap & & & & $0,000^{*}$ \\
a. Intervensi & 31 & 81,45 & 8,742 & \\
b. Kontrol & 31 & 71,64 & 6,724 & 0,732 \\
Keterampilan hari pertama & & & & \\
a. Intervensi & 31 & 65,86 & 20,110 & $0,000^{*}$ \\
b. Kontrol & 31 & 61,63 & 14,340 & \\
Keterampilan hari kedua & & & & \\
a. Intervensi & 31 & 85,48 & 12,904 & $0,000^{*}$ \\
b. Kontrol & 31 & 68,28 & 14,236 & \\
Keterampilan hari ketiga & & & & \\
a. Intervensi & 31 & 94,89 & 10,537 & \\
b. Kontrol & 31 & 67,20 & 13,154 & \\
Rerata skor keterampilan & & & & \\
a. Intervensi & 31 & 82,08 & 13,154 & \\
b. Kontrol & 31 & 65,77 & 10,537 & \\
\hline
\end{tabular}

*Bermakna pada $\alpha=0,05$

\section{Hasil}

\section{Karakteristik Responden}

Ibu yang merawat anak diare di RS A dan RS B Denpasar rerata berusia di bawah 30 tahun, pada kelompok kontrol rerata berusia 28,74 tahun dan kelompok intervensi rerata berusia 29,52 tahun. Tingkat pendidikan ibu sebesar $38,7 \%$ pendidikan dasar (SD, SLTA) dan 50\% pendidikan SLTA. Sebagian besar ibu tidak mempunyai pengalaman merawat anak diare di rumah sakit yaitu $88,7 \%$ dan pernah mendapat informasi tentang diare $58,1 \%$.

\section{Perbedaan Kemampuan Ibu Merawat Anak Diare pada Kelompok Intervensi dan Kelompok Kontrol}

Hasil analisis pada tabel 1 menunjukkan bahwa skor pengetahuan ibu pada kelompok intervensi lebih tinggi dibanding dengan kelompok kontrol $(p=0,000 ; \alpha=0,05)$. Skor sikap ibu pada kelompok intervensi juga lebih tinggi dibanding kelompok kontrol ( $p=0,000 ; \alpha=0,05)$. Hasil observasi pada keterampilan menunjukkan bahwa tidak adanya perbedaan bermakna skor keterampilan ibu di hari pertama kedua kelompok responden $(p=0,732 ; \alpha=$ $0,05)$. Namun analisis lebih lanjut didapatkan bahwa skor keterampilan di hari kedua dan ketiga menunjukkan skor yang lebih tinggi pada kelompok intervensi dibanding dengan kelompok $\operatorname{kontrol}(\mathrm{p}=$ $0,000 ; \alpha=0,05)$.

Kemampuan ibu dinilai berdasarkan pada aspek pengetahuan, sikap, dan keterampilan. Kategori dibuat berdasarkan kriteria; pengetahuan yang baik apabila skor yang diperoleh $\geq 75$, sikap positif apabila skor yang diperoleh $\geq$ mean $(75,48)$ dan keterampilan baik apabila skor $\geq 80$. Ibu dikatakan mampu apabila memenuhi 2 kategori tersebut.

Hasil analisis pada tabel 2 menunjukkan bahwa sebagian besar $(90,3 \%)$ ibu yang mendapatkan pendidikan kesehatan mampu merawat anak diare, sedangkan ibu yang tidak mendapat pendidikan kesehatan hanya sebanyak 19,4\% yang mampu merawat anak dengan diare. Kemampuan ibu yang mendapat intervensi pendidikan kesehatan lebih besar dibandingkan dengan yang tidak diberikan $(p=0,000 ; \alpha=0,05)$. 
Hasil analisis dapat disimpulkan bahwa ibu yang mendapatkan pendidikan kesehatan perawatan anak dengan diare berpeluang sebesar 4,667 kali untuk mampu merawat anak diare dibandingkan dengan ibu yang tidak mendapatkan pendidikan kesehatan $(\mathrm{RR}=4,667)$.

\section{Pembahasan}

\section{Karakteristik Responden}

Peneliti menilai karakteristik responden pada kedua kelompok untuk menentukan apakah ibu pada kedua kelompok berbeda. Hasil analisis pada uji homogenitas ditemukan bahwa tidak ada perbedaan yang bermakna dalam karakteristik responden pada kedua kelompok sehingga membantu memastikan keabsahan/validitas internal dari penelitian, bahwa pengetahuan, sikap, dan keterampilan ibu dalam merawat anak diare pada kelompok intervensi adalah efek dari paket pendidikan kesehatan yang diberikan.

\section{Perbedaan Pengetahuan Ibu yang Diberikan dengan yang Tidak Diberikan Pendidikan Kesehatan Perawatan Anak Diare}

Skor pengetahuan yang diperoleh masing-masing kelompok ini menunjukkan skor pengetahuan ibu pada kelompok intervensi lebih tinggi dibanding dengan kelompok kontrol. Pengetahuan ibu tentang definisi diare, bahaya diare, waktu harus datang ke tempat pelayanan kesehatan, dan peran ibu dalam manajemen diare di rumah meningkat bermakna setelah diberikan pendidikan kesehatan (Houroun, 2010). Pranowo (2009) juga menemukan bahwa ada perbedaan yang bermakna antara pengetahuan responden yang diberikan pendidikan kesehatan dengan yang tidak diberikan pendidikan kesehatan.

\section{Perbedaan Sikap Ibu yang Diberikan dengan yang Tidak Diberikan Pendidikan Kesehatan Perawatan Anak Diare}

Rerata skor sikap ibu pada kelompok intervensi lebih tinggi dibanding dengan kelompok kontrol. Menurut Notoatmodjo (2010), sikap adalah respon tertutup seseorang terhadap stimulus atau objek tertentu yang sudah melibatkan faktor pendapat, dan emosi yang bersangkutan. Dalam penentuan sikap yang utuh, bahwa pengetahuan, pikiran, keyakinan, dan emosi memegang peranan penting.

Pendidikan kesehatan perawatan anak dengan diare merupakan salah satu sumber informasi untuk responden sehingga mengetahui tentang penyakit diare terkait dengan penyebab, bahaya, pencegahan, perawatan selama di rumah sakit, dan lain-lain. Pengetahuan ini akan membuat ibu berfikir dan berupaya agar anak cepat sembuh dan terhindar dari diare lagi dengan melakukan perawatan dan upayaupaya pencegahan sesuai anjuran.

\section{Perbedaan Keterampilan Ibu yang Diberikan dengan yang Tidak Diberikan Pendidikan Kesehatan Perawatan Anak Diare}

Keterampilan responden diukur selama 3 hari pengamatan, dimana intervensi diberikan pada hari kedua. Skor yang dipakai untuk menentukan skor keterampilan post test yaitu skor keterampilan pada hari ketiga. Tidak adanya perbedaan skor keterampilan responden sebelum diberi pendidikan kesehatan antara kelompok kontrol dan intervensi.

Tabel 2. Kemampuan Ibu Merawat Anak Diare setelah Periode Intervensi

\begin{tabular}{|c|c|c|c|c|c|c|c|c|c|}
\hline \multirow{2}{*}{ Perlakuan } & \multicolumn{2}{|c|}{ Mampu } & \multicolumn{2}{|c|}{ Kurang Mampu } & \multicolumn{2}{|c|}{ Total } & \multirow{2}{*}{ RR $(95 \%$ CI) } & \multirow{2}{*}{$\mathbf{X}^{2}$} & \multirow{2}{*}{$\mathbf{p}$} \\
\hline & f & $\%$ & f & $\%$ & f & $\%$ & & & \\
\hline Penkes $(+)$ & 28 & 90,3 & 3 & 9,7 & 31 & 100 & $\begin{array}{c}4,667 \\
(2,254-9,662)\end{array}$ & 28,72 & $0,000^{*}$ \\
\hline Penkes (-) & 6 & 19,4 & 25 & 80,6 & 31 & 100 & 1 & & \\
\hline Jumlah & 34 & 54,8 & 28 & 45,2 & 62 & 100 & & & \\
\hline
\end{tabular}

*Bermakna pada $\alpha=0,05$ 
Kondisi yang berbeda terlihat pada hari kedua dan ketiga, skor keterampilan kelompok yang mendapat pendidikan kesehatan meningkat dibandingkan dengan hari pertama. Skor keterampilan kelompok intervensi pada hari kedua dan ketiga lebih tinggi dibandingkan dengan kelompok kontrol.

Hasil penelitian ini sejalan dengan yang dilakukan oleh Yurika (2009), bahwa pendidikan kesehatan dapat meningkatkan keterampilan ibu dalam memantau pertumbuhan dan perkembangan balita. Penelitian Muhamadi (2009) menemukan bahwa tingkat pengetahuan yang baik secara bermakna berpengaruh terhadap tindakan pencegahan diare pada balita, dan sikap ibu yang positif secara bermakna juga berpengaruh terhadap tindakan pencegahan diare pada balita.

\section{Pengaruh Paket Pendidikan Kesehatan Perawatan Anak Diare terhadap Kemampuan Ibu Merawat Anak Diare di Rumah Sakit}

Hasil post test pada kedua kelompok menunjukkan mayoritas ibu pada kelompok intervensi mampu merawat anak dengan diare, sedangkan pada kelompok kontrol hanya sebagian kecil. Proporsi ibu yang mampu merawat anak dengan diare pada kelompok intervensi lebih besar dibanding dengan kelompok kontrol.

Hasil penelitian ini sesuai dengan penelitian yang dilakukan oleh Redjeki (2005), mengidentifikasi kemampuan dan kepuasan ibu terhadap pendidikan kesehatan mengenai stimulasi perkembangan di Depok. Redjeki dalam penelitiannya mendapatkan hasil bahwa adanya peningkatan secara bermakna terhadap kemampuan (pengetahuan, sikap, dan keterampilan) ibu sebelum dan sesudah diberikan pendidikan kesehatan.

Hasil penelitian Mishra, Sinta, dan Salam (2008), yang juga menemukan bahwa peningkatan yang bermakna terhadap faktor pengetahuan, sikap, dan keterampilan ibu pada kelompok intervensi terkait berbagai aspek perawatan anak seperti personal higiene, penyebab diare, pentingnya imunisasi, ASI, dan penyapihan.
Paket pendidikan kesehatan anak dengan diare efektif digunakan agar ibu mampu merawat anak dengan diare di rumah sakit. Apabila ibu/orangtua sudah memiliki kemampuan merawat anak dengan diare, maka ibu akan mudah bekerjasama dalam perawatan anak, sehingga konsep family centered care $(F C C)$ dapat diterapkan dan mencapai hasil asuhan keperawatan yang optimal.

Responden dalam penelitian ini adalah ibu-ibu yang anaknya dirawat dengan diare dan berusia antara 0-59 bulan. Usia balita memiliki ketergantungan yang tinggi dengan orangtua sehingga kerjasama anatara perawat dengan orangtua selama perawatan anak sangat dibutuhkan. Keluarga, khususnya ibu adalah orang yang paling mengetahui hal yang dibutuhkan oleh anak.

Konsep yang mendasari asuhan yang berpusat pada keluarga adalah memfasilitasi keterlibatan orang tua dalam perawatan dan peningkatan kemampuan keluarga merawat anak. Orangtua yang diharapkan mempunyai kesempatan meneruskan peran dan tugasnya merawat anak selama di rumah sakit (Supartini, 2005). Salah satu upaya yang dapat dilakukan perawat untuk memfasilitasi keterlibatan orangtua dalam perawatan anak adalah dengan memberikan pendidikan kesehatan.

\section{Kesimpulan}

Pendidikan kesehatan keluarga perawatan anak diare terbukti efektif meningkatkan kemampuan ibu dalam merawat anak dengan diare di rumah sakit. Pengetahuan, sikap, dan keterampilan yang baik dalam perawatan anak dengan diare dapat mendukung terlaksananya konsep family centered care dalam memberikan asuhan keperawatan anak di rumah sakit. Bagi pemegang kebijakan di rumah sakit, khususnya ruang perawatan anak, hendaknya membuatkan satu kebijakan untuk memberikan pendidikan kesehatan perawatan anak dengan diare secara lebih intensif dan terstruktur serta mempertimbangkan media poster, leaflet, atau audiovisual sehingga dapat lebih efektif dan efisien (WK, NN, HP). 


\section{Referensi}

Assiddiqi, M.H. (2010). Tingkat pengetahuan ibu terhadap penanganan diare pada balita di kelurahan padang bulan kecamatan medan baru (Karya tulis ilmiah, Fakultas Kedokteran Universitas Sumatera Utara). Fakultas Kedokteran Universitas Sumatera Utara, Medan. Diperoleh dari http://repository.usu.ac.id.

Ariawan, I. (1998). Besar dan metode sampel pada penelitian kesehatan (Tesis master, tidak dipublikasikan). Biostatistik dan Kependudukan Fakultas Kesehatan Masyarakat Universitas Indonesia, Jakarta.

Bachrach, \& Gardner. (2002). Caregiver knowledge, attitudes, and practices regarding childhood diarrhea and dehydration in Kingston, Jamaica. Pan American Journal Public Health, 12 (1), 37-44.

Emily, E.T.S., \& Tony, N.B. (2010). Evaluating the health belief model: A critical review of studies predicting mammographic, and pap screening. Social Theory \& Health, 8, 95-125.

Haroun,H.M., Mahfouz, M.S., Mukhtar, M.E., \& Salah, A. (2010). Assessment of the effect of health education on mothers in Al Maki area, Gezira state, to improve homecare for children under five with diarrhea. Journal of family \& Community Medicine, 17 (3), 141-146.

Handayani, Y.R. (2008). Gambaran tingkat pengetahuan ibu tentang perawatan balita diare di RSUD Dr. Hardjono Ponorogo. Diperoleh dari http://library-ump.org.

Khalili, B., Gorbanali, S., Khalili, M., Mardani, M., \& Cuevas, L.E. (2006). Risk factors for hospitalization of children with diarrhea in Shahrekord, Iran. Iranian Journal of Clinical Infectious Diseases, 1 (3), 131-136.

Muhamadi, I. (2009). Hubungan pengetahuan dan sikap ibu terhadap pencegahan penyakit diare Didesa Tumbang Manjul Kecamatan Seruyan Hulu Kabupaten Seruyan Kalimantan Tengah (Tesis Master, Program Studi Ilmu Keperawatan Universitas Diponegoro). Fakultas Kedokteran Program Studi Ilmu Keperawatan Universitas Diponegoro, Semarang. Diperoleh dari http:// eprints.undip.ac.id.
Notoatmodjo, S. (2010). Ilmu perilaku kesehatan. Jakarta: Rineka Cipta.

Pranowo, A.E. (2009). Efektifitas pendidikan kesehatan tentang diare pada balita di Desa Pucangan wilayah kerja Puskesmas Kartasura I kabupaten Sukoharjo (Skripsi, Program Studi Keperawatan Universitas Muhammadiyah Surakarta). Fakultas Ilmu Kesehatan Program Studi Keperawatan Universitas Muhammadiyah Surakarta, Jawa Tengah. Diperoleh dari http://etd.eprints.ums. ac.id.

Redjeki, G.S. (2005). Kemampuan dan kepuasan ibu terhadap pendidikan kesehatan mengenai stimulasi perkembangan anak usia toddler di Kelurahan Kemirimuka Depok (Tesis master, Fakultas Ilmu Keperawatan). Fakultas Ilmu Keperawatan Universitas Indonesia, Jakarta. Diperoleh dari http://eprints.lib.ui.ac.id.

Subagyo, B., \& Santoso, N.B. (2011). Diare akut, dalam Buku ajar gastroenterologi-hepatologi (Cetakan kedua). Jakarta: Ikatan Dokter Anak Indonesia.

Supartini, Y. (2004). Konsep dasar keperawatan anak. Jakarta: Penerbit Buku Kedokteran EGC

Warman, Y. (2008). Hubungan faktor lingkungan, sosial ekonomi dan pengetahuan ibu dengan kejadian diare akut pada balita di Kelurahan Pekan Arba Kecamatan Tembilahan Kabupaten Indragiri Hilir (Skripsi, Kedokteran Universitas Riau). Fakultas Kedokteran Universitas Riau, Riau. Diperoleh dari http://lib.unri.ac.id.

Yurika. (2009). Efektifitas pendidikan kesehatan terhadap pengetahuan, sikap, dan ketrampilan ibu dalam pemantauan perkembangan balita (Tesis master, tidak dipublikasikan). Fakultas Ilmu Keperawatan Universitas Indonesia, Jakarta. 